\title{
Analisis Politik dan Kebenaran: Membandingkan Pemikiran Arendt dan Foucault
}

\author{
M. Rizky Prawira \\ International Relations Department, Faculty of Social and Political Sciences, \\ Universitas Sulawesi Barat muhammadrizkyprawira@gmail.com
}

\begin{abstract}
ABSTRAK
Istilah politik dan kebenaran telah secara umum dipergunakan bersama-sama dan dipadankan di masyarakat tanpa suatu pendefinisian yang jelas. Hal ini membuat penggunaan kedua term atau istilah ini menjadi ambigu dan tumpang tindih. Selain itu, dari sisi teori dan praktiknya sendiri, hubungan antar politik dan kebenaran masih belum dapat ditelaah oleh masyarakat luas. Sebagai tindak lanjut dari isu ini, paper ini menguraikan konsep kebenaran (truth) dan politik (politics) dari Hannah Arendt dan teori kekuasaan (power), pengetahuan (knowledge) dan kebenaran (truth) dari Michel Foucault. Setelah itu, paper ini melakukan perbandingan antar kedua teori ini dengan tujuan untuk mengetahui gambaran yang tepat mengenai hubungan antara politik dan kebenaran serta sejauh mana keduanya dapat dipisahkan satu sama lain. Melalui analisis perbandingan kedua teori terkait hubungan antara politik dan kebenaran ilmiah atau kebenaran rasional, dapat disimpulkan bahwa seberapa jauh kebenaran ilmiah dapat dipisahkan dari politik akan ditentukan melalui cara kebenaran tersebut didapatkan. Jika suatu kebenaran ilmiah didapatkan sendiri atau secara independen, tanpa suatu proses penelitian yang melibatkan pihak lain serta institusi, maka kebenaran tersebut tetap dapat berada di luar wilayah politik, jika tidak, kebenaran tersebut pasti akan menjadi elemen hubungan manusia yang bersifat politis.
\end{abstract}

Kata Kunci: Politik, Kebenaran, Hannah Arendt, Michel Foucault

\section{Pendahuluan}

Terkadang cukup rumit untuk mengasosiasikan kebenaran (truth) dengan politik (politics). Kedua istilah ini sudah secara umum digunakan bersama-sama tanpa didefinisikan dengan sempurna. Situasi ini menciptakan ambiguitas dimana penggunaan istilah politik dan kebenaran dalam berbagai diskursus terkadang menjadi tidak jelas dan tumpang tindih. Di samping itu, terdapat beberapa alasan mengapa sangat penting untuk mengeksplorasi lebih lanjut tentang hubungan antara keduanya serta memahami perannya dalam masyarakat. Pertama, banyak orang tidak benar-benar tahu apa itu kebenaran ataupun politik. Dalam hal ini, mereka lebih banyak mengandalkan interpretasi personal mereka untuk membedakan kedua istilah ini. Situasi ini diperparah dengan tidak adanya kesadaran untuk mencari penjelasan yang lebih 
komprehensif mengenai kedua hal ini. Lebih jauh, begitu konsep yang jelas tentang kebenaran dan politik didapatkan, tidak selalu mudah untuk menjelaskan korelasi antara keduanya. Beberapa orang belum memahami bagaimana politik dapat mempengaruhi kebenaran, atau sebaliknya. Selain itu, salah satu perdebatan besar mengenai hal ini, adalah untuk mengetahui apakah politik dan kebenaran adalah dua entitas yang terpisah atau apakah mereka terdapat dalam suatu ranah yang sama. Oleh karena itu, cukup penting untuk mencari tahu apakah ada suatu kebenaran yang independen; sama sekali tidak berhubungan dengan politik, atau tidak. Untuk menindaklanjuti ini, pertama-tama kita akan menguraikan konsep kebenaran dan politik dari Hannah Arendt dan teori kekuasaan (power), pengetahuan (knowledge) dan kebenaran (truth) dari Michel Foucault.

Paper ini bertujuan untuk mendapatkan pemahaman teoritis yang tepat untuk menjawab dua pertanyaan awal. Pertama, apakah kebenaran dan politik menurut konsep Arendt? Kedua, apa gagasan utama kekuatan, pengetahuan, dan kebenaran dari Foucault? Setelah itu, paper ini membandingkan teori Arendt dengan Foucault untuk menjawab satu pertanyaan utama; Sejauh mana kebenaran dapat dipisahkan dari politik? Dengan menjawab pertanyaan-pertanyaan ini, kita dapat menemukan perspektif yang memungkinkan kita memahami ide dasar tentang bagaimana kebenaran dan politik saling berhubungan.

\section{Hannah Arendt: Kebenaran dan Politik}

Hannah Arendt telah memberikan konsep yang jelas mengenai kebenaran dan politik dalam tulisannya Truth and Politics. Dalam bab ini, dia berpendapat bahwa istilah politik dan kebenaran sebenarnya bertentangan karena tidak ada tempat untuk kebenaran dalam politik (Arendt, 1993). Lebih jauh, dia menjelaskan kebenaran sebagai sesuatu yang "kita tidak dapat ubah; atau secara metaforis, kebenaran adalah tanah tempat kita berdiri dan langit yang membentang di atas kita"(Arendt, 1993, p 259). Di sisi lain, Arendt memberikan ide yang tidak biasa namun menarik tentang apa itu politik. Dia mendefinisikan kehidupan politik sebagai

"sukacita dan kepuasan yang muncul dari menjalin relasi dengan teman-teman kita, keluar dari bertindak bersama dan tampil di publik, dari memasukkan diri kita ke dunia melalui kata dan perbuatan, sehingga memperoleh dan mempertahankan identitas pribadi kita dan memulai sesuatu yang sama sekali baru"(Arendt, 1993, p 259). Dunia politik dalam konteks ini, menyangkut urusan manusia serta konstelasi ide dan pendapat dalam masyarakat, bukan hal-hal yang berkaitan dengan sistem negara atau struktur hierarkis dari pemerintahan.

Namun, dia mengakui dua jenis kebenaran berbeda; kebenaran rasional atau filosofis dan kebenaran faktual. Perselisihan antara politik dan kebenaran rasional adalah sorotan pertama dari benturan antara dua wilayah ini (Arendt, 1993)."Kebenaran filosofis ditemukan dan diaktualisasikan dalam kesendirian, serta menurut definisi, mentransendensikan, wilayah dari banyak orang, dunia urusan manusia" (Arendt, 1993, p. 233). 
Kebenaran rasional juga dapat dikategorikan sebagai kebenaran ilmiah, atau kebenaran matematika (Arendt, 1993). Oleh karena itu orang mungkin mengatakan bahwa jenis kebenaran ini menghuni dunia ilmiah, dan terdiri dari pernyataan ilmiah yang sepenuhnya di luar sistem kemasyarakatan. Misalnya, pernyataan "tiga sudut segitiga harus sama dengan dua sudut persegi" dapat dianggap sebagai produk kebenaran rasional (Arendt, 1993, p 226). Lebih jauh, Arendt sangat yakin bahwa kebenaran rasional yang dihasilkan oleh pikiran manusia memiliki sifat yang sangat kaku yang tampaknya tidak sesuai dengan sifat politik. Dia pada dasarnya berpendapat bahwa "kebalikan dari pernyataan yang benar secara rasional adalah kesalahan dan ketidaktahuan, seperti dalam sains, atau ilusi dan pendapat, seperti dalam filsafat" (Arendt, 1993, p 228). Ketidakpastian dalam pendapat serta opini manusia adalah kebalikan dari karakter kebenaran yang dibawa oleh para filsuf (Arendt, 1993). Dalam hal ini, konteks perdebatan yang terletak pada perselisihan antara pendapat dan fakta, atau benar dan salah secara alamiah, menjadi refleksi dari hubungan antara politik dan kebenaran rasional.

Sedikit berbeda dengan kebenaran rasional, kebenaran faktual terkait dengan politik. Arendt sendiri menguraikan beberapa konsep kebenaran faktual. Dalam hal ini, kebenaran faktual selalu terkait dengan orang lain: menyangkut peristiwa dan keadaan di mana banyak yang terlibat; ditetapkan oleh para saksi dan bergantung pada kesaksian; hanya ada sejauh yang dibicarakan, bahkan jika itu terjadi di domain privasi, kebenaran faktual selalu bersifat politis "(Arendt, 1993, p. 234).

Maka dapat dipahami bahwa tidak seperti kebenaran rasional, kebenaran faktual terdapat pada domain sosial atau hubungan manusia. Alih-alih terkait dengan sains atau filsafat, kebenaran faktual lebih berfokus pada hal-hal yang berkaitan dengan orang. Meskipun begitu, hubungan antara politik dan kebenaran faktual tidak selalu selaras. Kebenaran faktual dapat menderita nasib yang sama dengan kebenaran rasional jika dihadapkan pada politik, karena karakteristik keduanya yang cukup lemah terhadap para pemegang opini (Arendt, 1993). Bahkan, kebenaran faktual sangat rapuh setelah terpapar ke ranah publik, karena dapat dipengaruhi oleh, atau bahkan diubah menjadi opini (Arendt, 1993). Oleh karena itu, jelas bahwa tedapat masalah dalam hubungan antar keduanya.

Sebagai tambahan, Arendt juga menjelaskan bagaimana kebenaran dapat menandingi pemerintahan tirani. Kebenaran faktual dan rasional memiliki sifat tirani dan unsur paksaan, yang berarti bahwa pernyataan kebenaran dianggap sebagai sesuatu yang tidak terbantahkan, dan tidak mungkin untuk diperebutkan oleh pendapat manusia (Arendt, 1993). Dengan demikian, dari perspektif politik, kebenaran dapat dilihat sebagai ancaman, karena karakter despotiknya dapat menyebabkan persaingan dengan tiran yang memerintah (Arendt, 1993). Hal ini juga membuktikan bahwa kebenaran dapat menjadi lawan bagi penerapan politik secara umum (sistem negara, pemerintahan hierarkis).

Singkatnya, Arendt menjelaskan konsep kebenaran dan politik dengan membuat perbedaan antara kebenaran faktual dan kebenaran rasional. Kebenaran faktual dan kebenaran 
rasional berbenturan dengan dunia politik, tetapi keduanya berurusan dengan level hubungan manusia yang berbeda (Arendt, 1993). Hubungan manusia ini merepresentasikan praktik politik dalam masyarakat. Namun, lingkup politik ini dibatasi oleh sesuatu yang tidak dapat diubah sesuai keinginan, oleh karena itu penting untuk menyadari dan menghargai perbatasannya (Arendt, 1993, p 259). Jadi, cukup aman untuk berasumsi bahwa berdasarkan teori Arendt, ada batas yang jelas yang memisahkan politik dari kebenaran dan sebaliknya.

\section{Michel Foucault: Kekuasaan, Pengetahuan, dan Kebenaran}

Foucault menawarkan pendekatan yang sangat berbeda dalam melihat kebenaran dan politik. Selain itu, ia kebanyakan menggunakan istilah 'kekuasaan' (power) bukan politik. Dia mendefinisikan kekuasaan sebagai hak bagi orang untuk memiliki akses ke komoditas dan memiliki otoritas untuk mentransfernya melalui mekanisme atau tindakan hukum (Foucault, 1976). Kekuasaan juga sesuatu milik individu yang "memungkinkan kekuasaan politik atau kedaulatan untuk didirikan" (Foucault, 1976, p. 88). Dalam konteks ini, kita mungkin berpendapat bahwa karena konsep politik Foucault melibatkan kekuasaan, otoritas, dan kedaulatan, terdapat elemen hierarkis, dominasi, dan represi yang memungkinkan sistem komando top-down untuk diterapkan. Kekuasaan bukanlah sesuatu yang diberikan, melainkan dipraktekkan (Foucault 1976). "Kekuasaan merepresi alam, naluri, kelas, dan individu, dan

kekuasaan sebagai bentuk represi juga telah menjadi bagian dalam wacana modern" (Foucault, 1976, p. 89).

Namun, harus dipahami bahwa wacana kekuasaan ini ditransmisikan ke dalam individu. Atau dengan kata lain, praktik politik sebenarnya diartikulasikan melalui kegiatan individu. Dengan demikian, masih ada beberapa hubungan antara konsep kekuasaan Foucault dan konsep politik Arendt karena keduanya sebenarnya berkaitan dengan hubungan manusia. Foucault mengakui hubungan erat antara kekuasaan, pengetahuan, dan kebenaran. Ada hubungan kekuasaan dalam masyarakat yang tidak dapat dibangun tanpa pembentukan wacana (Foucault, 1976). Lebih lanjut, dia juga berpendapat bahwa masyarakat "tunduk pada produksi kebenaran melalui kekuasaan dan kita tidak dapat menjalankan kekuasaan kecuali melalui produksi kebenaran" (Foucault, 1976, p. 93). Jadi, pengetahuan dan kebenaran dalam hal ini, bukanlah sesuatu yang given atau 'sudah ada', melainkan produk-produk dari wacana yang dibentuk oleh kekuasaan. Di sisi lain, kebenaran dan pengetahuan ini juga penting untuk menjalankan praktik kekuasaan itu sendiri. Singkatnya, tidak seperti teori Arendt, hubungan antara kekuasaan dan kebenaran menurut Foucault saling konstitutif. Kekuatan, pengetahuan, dan konsepsi kebenaran Foucault dalam hal sains juga menunjukkan ide-ide serupa. Misalnya, Foucault berpendapat bahwa "praktik psikiatri sebenarnya berkaitan erat dengan berbagai macam institusi, persyaratan ekonomi, dan masalah politik peraturan sosial" (Foucault, 1977, p. 109). Selain itu, ada juga hubungan yang erat antara jenis ilmu lain, seperti kedokteran dengan struktur sosial (Foucault, 1977). 
Di sisi lain, McWhorter menguraikan ide-ide Foucault lebih jauh dan menemukan hubungan antara isu rasial dalam masyarakat dengan perkembangan biologi sebagai ilmu. Setelah beberapa analisis historis, ia muncul dengan pernyataan bahwa "biologi tidak hanya alat yang diperlukan untuk disiplin ilmu, namun sangat mungkin ilmu biologi sebenarnya didasari oleh kekuasaan" (McWhorter, 1995, p 179). Oleh karena itu, kebenaran dalam bentuk penemuan ilmiah juga saling konstitutif dengan kekuasaan (McWhorter, 1995).

\section{Analisis: Membandingkan Teori Arendt dengan Teori Foucault}

Bagian ini akan menganalisis kedua teori, dan mencari tahu sejauh mana kebenaran dapat dipisahkan dari politik. Namun, untuk membuat perbandingan yang tepat kita perlu terlebih dahulu mencari tahu aspek-aspek antara kedua teori (Arendt dan Foucault) yang sebenarnya dapat dibandingkan karena masing-masing dari mereka memiliki perspektif sendiri dalam mendefinisikan kebenaran dan politik. Oleh karena itu, sangat penting untuk membatasi ruang lingkup analisis secara lebih terkhusus untuk menghindari kesimpulan yang keliru. Dalam hal ini, kita dapat mengeksplorasi lebih jauh tentang hubungan antara dunia ilmiah dan politik karena kedua ahli teori mengakui ilmu pengetahuan sebagai bentuk kebenaran. Mengingat bahwa kebenaran faktual jelas terkait dengan urusan manusia, fokus pembahasan sebenarnya terletak pada cara Arendt memandang kebenaran rasional atau ilmiah sebagai sesuatu di luar politik dan perbandingannya dengan relasi kekuasaan-ilmu milik Foucault. Dengan membandingkan kedua konsep ini, kita akan mengetahui sejauh mana kebenaran ilmiah itu mungkin atau mungkin tidak terkait dengan politik atau ranah kemasyarakatan.

Arendt dengan jelas berpendapat bahwa tidak seperti kebenaran faktual, kebenaran rasional sebenarnya ada di dalam individu dalam kesendiriannya (Arendt, 1993). Ini sangat kontradiktif dengan konsep Foucault yang menekankan bahwa kebenaran adalah kekuasaan yang dihasilkan, dan sebaliknya. Dalam hal ini, karena kedua ahli teori memiliki gagasan politik yang berbeda, setidaknya kita dapat menganggap bahwa sejauh mana kebenaran ilmiah dapat dipengaruhi oleh hubungan manusia, atau melangkah di luar kesendirian akan mewakili cara kebenaran dan politik saling terkait satu sama lain. McWhorter berpendapat bahwa ilmu pengetahuan, seperti biologi didahului oleh tujuan administratif yang memungkinkannya untuk berkembang (McWhorter, 1995). Praktik biologi sebagai ilmu dalam mengkategorikan manusia berdasarkan fitur fisik dan material pada dasarnya didasari oleh tujuan dan sasaran tertentu (misalnya: manajemen, kesehatan, umur panjang, dll.) yang telah ditetapkan jauh sebelumnya (McWhorter, 1995). Dengan demikian, peran lembaga dan kepentingan manusia telah terbukti dalam penciptaan biologi sebagai ilmu. Ini memang sangat jauh berbeda dari konsep sains sebagai sesuatu yang berada di luar ranah sosial manusia.

Sebagai contoh konkret, penemuan biologis individu yang mengalami degenerasi atau 'kelompok masyarakat' yang berbeda dari populasi lainnya membantu membangun struktur 
hirarkis kekuasaan berdasarkan ras (McWhorter, 1995). Dalam hal ini, riset di bidang biologis menemukan jenis gen bawaan manusia dan menempatkan kelompok manusia dengan DNA bawaan yang cenderung lemah dan tidak sempurna dalam kelompok yang berbeda dengan kelompok masyarakat lain. Hal ini sedikit banyak menkonstruksi stratifikasi rasial manusia sebagaimana yang kita kenal sekarang, khususnya berkaitan dengan segregasi kelompok masyarakat kulit putih (gen kuat) dan kulit gelap (gen lemah). Lebih jauh, "riset-riset yang dilakukan untuk mempelajari karakteristik genetis manusia akan lebih jaut mempertegas klasifikasi rasial ini, karena kemungkinan besar terdapat suatu korelasi antara ras dan daya tahan terhadap penyakit maupun reaksi dalam obat dan pengobatan" (Wasserman, 2010, p. 215). Dengan demikian, jelaslah bahwa ada suatu siklus hubungan timbal-balik dimana kekuasaan berperan dalam menghasilkan pengetahuan atau kebenaran, dan di sisi lain, sains berfungsi untuk menemukan pengetahuan bagi keberadaan kekuasaan.

Masalah berikutnya untuk dipecahkan adalah menentukan jenis kebenaran ilmiah yang sebenarnya terpisah dari politik. Arendt mungkin berpendapat bahwa pernyataan biologis seperti "jenis gen tertentu tidak selaras yang lain" adalah kebenaran rasional karena pernyataan ini tidak berkaitan dengan suatu peristiwa di masyarakat (yang akan menempatkannya di antara kebenaran faktual), dan mengacu pada sesuatu yang hampir tidak mungkin untuk diubah. Namun, kita dapat berpendapat bahwa menurut teori Foucault, pernyataan jenis ini bisa sangat politis, baik dilihat melalui proses yang mengarah pada pernyataan ini atau dampak politik yang mungkin ditimbulkannya. Ini memang membuka celah antara dua teori yang perlu dianalisis untuk menjawab masalah. Dalam hal ini, klasifikasi kebenaran yang disampaikan Arendt dapat dipertanyakan atau setidaknya dikaji lebih lanjut dimana perlu disediakan ruang untuk jenis kebenaran ilmiah yang tidak hanya menyangkut pada hal-hal yang bersifat absolut dan kaku, melainkan menjadi bagian dari urusan manusia.

Jawaban atas masalah ini mungkin terletak pada proses di mana kebenaran ilmiah ini dibuat atau didapatkan. Dalam konteks ini, kita harus mempertimbangkan semua aspek, baik mekanisme yang mendahului perumusan kebenaran ilmiah tersebut dan orang-orang yang terlibat di dalamnya. Kebenaran ilmiah mungkin lebih dari sekadar pernyataan yang nampak di permukaan, namun bisa juga mengandung nilai-nilai yang menghubungkannya dengan politik. Konsep kebenaran rasional Arendt masih sangat relevan ketika tidak ada pengaruh eksternal terhadap seorang ilmuwan atau filsuf. Ia harus tetap dalam kesendirian dan menghindari sentuhan apa pun dengan dunia luar. Atau dengan kata lain, seorang individu tidak boleh terlibat dalam interaksi apa pun yang mungkin mengarahkan atau secara tidak langsung mempengaruhi temuannya tentang kebenaran. Ini juga berarti bahwa penelitian harus dilakukan dengan sangat independen di semua aspek tanpa kepentingan apapun atau bahkan tujuan tertentu untuk dicapai. Di sisi lain, begitu kebenaran ilmiah dihasilkan melalui mekanisme penelitian terpadu yang melibatkan lembaga, sifat politiknya tidak lagi dapat disangkal. Keterlibatan institusi dalam hal ini mewakili peran kekuasaan, dan tidak peduli seberapa autentik hasil penelitian itu, hanya akan menjadi alat untuk memenuhi tujuan politik tertentu. 


\section{Kesimpulan}

Paper ini berusaha membangun perspektif untuk memahami cara kebenaran berhubungan dengan politik, dan sebaliknya melalui dua langkah penting. Pertama, melalui elaborasi ide-ide kebenaran (truth) dan politik (politics) dari Arendt dan Foucault, landasan teoritis yang sesuai berhasil didapatkan. Kedua, paper ini membandingkan dua teori untuk menemukan pemahaman yang layak untuk menjawab pertanyaan utama. Dalam hal ini, perbandingan dibuat dengan memfokuskan lingkup analisis ke dalam hubungan antara ilmu pengetahuan sebagai kebenaran ilmiah dengan politik. Secara garis besar, seberapa jauh kebenaran ilmiah dapat dipisahkan dari politik akan ditentukan melalui cara kebenaran tersebut didapatkan. Jika kebenaran hanya ditemukan dalam kesendirian, tanpa suatu proyek penelitian yang melibatkan pihak lain, maka dia bisa tetap berada di luar wilayah politik, jika tidak, kebenaran itu pasti akan menjadi elemen hubungan manusia. Sebagai tambahan, kita harus sadar bahwa penting untuk menilai suatu kebenaran ilmiah, bukan hanya berdasarkan keaslian dan relevansi pernyataan kebenaran tersebut tetapi juga berdasarkan pada proses dan tujuan dari temuannya. 


\section{Referensi:}

Arendt, H. (1993). Between Past and Future: Eight Exercises in Political Thought (p 222-259). Penguin Books.

Foucault, M. (1976). Two Lectures. In C. Gordon (Ed), Power/Knowledge Selected Interview and Other Writings 1972-1977 (p78-108). New York, Pantheon Books.

Foucault, M. (1977). Truth and Power. In C. Gordon (Ed), Power/Knowledge Selected Interview and Other Writings 1972-1977 (p109-133). New York, Pantheon Books.

McWhorter, L. (1995). Scientific Discipline and the Origins of Race: A Foucaultian Reading of the History of Biology. In Babich, Babette E, Debra B. Bergoffen, and Simon Glynn (Eds), Continental and Postmodern Perspectives in the Philosopy of Science (p173-188). Aldershot, Hants: Avebury.

Wasserman, D. (2010) The Justifiability of Racial Classification and Generalizations in Contemporary Clinical and Research Practice. Law Probability and Risk 9, pp. 215-228 